\title{
STRATEGI PELAYANAN BIMBINGAN SOSIAL DAN KETERAMPILAN \\ PADA PANTI SOSIAL KARYA WANITA RUHUI RAHAYU \\ DI PALANGKA RAYA
}

\author{
Sumarnie $^{1}$ \\ ${ }^{1}$ Program Studi PLS FKIP Universitas Palangka Raya \\ Jl. H. Timang Komplek Kampus Tunjung Nyaho Palangka Raya
}

\begin{abstract}
ABSTRAK
Penelitian ini bertujuan untuk memperoleh gambaran tentang strategi: 1) Perencanaan pelayanan bimbingan sosial dan keterampilan pada PSKW Ruhui Rahayu di Palangka Raya, 2) Pengorganisasian, pelayanan bimbingan sosial dan keterampilan pada PSKW Ruhui Rahayu di Palangka Raya. 3) Pelaksanaan pelayanan bimbingan sosial dan keterampilan pada PSKW Ruhui di Palangka Raya, 4) dan Evaluasi Pelaksanaan pelayanan bimbingan sosial dan keterampilan pada PSKW Ruhui Rahayu di Palangka Raya.

Penelitian ini menggunakan metode deskriptif kualitatif dengan rancangan studi kasus. Pengumpulan data menggunakan tehnik wawancara,observasi dan dokumentasi. Data yang terkumpul diolah dianalisiskan dengan tahap reduksi data ,penyajian data, dan penarikan kesimpulan. Untuk menjamin validitas data dilakukan dengan triangulasi yaitu melalui sumber data lain dari sumber data utama. Hasil penelitian ini menunjukan bahwa: 1) perencanaan telah dilaksanakan dengan baik, hal ini terlihat dari perencanaan kegiatan yang berpedoman pada tahapan kegiatan berdasarkan (a) assesmen kebutuhan dan desain pelayanan, (b) penentuan tujuan pelayanan, (c) penetapan materi panduan pelayanan, (d) penetapan instruktur, (e) penetapan metode dan media, (f) menentukan fasilitas, (g) penetapan anggaran dan (h) penetapan jadwal /waktu pelayanan untuk mencapai hasil yang diharapkan berupa kehadiran warga belajar. 2) Pengorganisasian telah dilaksanakan dengan baik hal ini terlihat dengan adanya: (a). Penetapan struktur organisasi dan pembagian tugas, ((b) penetapan wewenang dan tanggung jawab, (c) pelaksanaan pelayanan bimbingan berjalan dengan lancar dan berhasil yang sepenuhnya mencerminkan karakteristik dan ciri-ciri pengelolaan yang efektif, (4) Evaluasi (pengawasan) secara prosedural sudah dilaksanakan secara efektip, hal ini terlihat dari evaluasi yang dilaksanakan yaitu evaluasi tingkat reaksi, evaluasi tingkat belajar, evaluasi tingkat prilaku dan evaluasi tingkat dampak. Dampak yang diperoleh warga belajar setelah mengikuti latihan keterampilan bimbingan sosial keterampilan, terbukanya kesempatan kerja untuk meningkatkan produktivitas kerja yang berdampak pada peningkatan pendapatan warga belajar untuk meningkatkan kesejahteraan hidupnya.
\end{abstract}

Kata Kunci : Bimbingan Sosial dan Keterampilan, Panti Sosial 


\section{PENDAHULUAN}

Pembangunan Nasional diarahkan pada pembangunan disegala bidang baik pembangunan fisik maupun pembangunan mental, yang mengarah kepada pembangunan sumber daya manusia yang memilki kompetensi profesional maupun komptensi kepribadian yang luhur sebagaimana cita-cita dalam tujuan pembangunan nasional Bangsa Indonesia yang adil dan makmur, merata dan berkeadilan, baik materil maupun spiritual berdasarkan Pancasila dan Undang-undang Dasar 1945. Untuk mewujudkan hal tersebut mebutuhkan sumber daya manusia yang berkualitas, tidak hanya dilakukan disekolah saja, tetapi dilakukan diluar sekolah yang didalamnya terjadi berbagai proses latihan keterampilan yang bersifat spesifik yang bermuara kepada penguasaan skill individu.

Salah satu bentuk lembaga Non Formal adalah PSKW yang menampung peserta dari kaum wanita yang berusia 16-35 tahun yang tergolong rawan sosial dan ekonomi. Kegiatan bimbingan yang dilakukan oleh pekerja sosial dirancang untuk membimbing, melatih dan membelajarkan warga belajar agar memiliki bekal dalam menghadapi masa depan dengan memanfaatkan peluang yang ada, Kegiatan keterampilan yang diselenggarakan melalui jalur luar sekolah diarahkan untuk mempersiapkan warga belajar memiliki keterampilan.

Dalam pengembangan program pelayanan bimbingan sosial dan keterampilan pekerja sosial langsung menangani strategi pelayanan dalam pengelolaan terdapat serangkaian aktivitas dilakukan secara sistematis, terkoordinir secara efektip dan efisien. Dengan hasil yang diharapkan dalam pelaksanaan kegiatan yang diselenggarakan dapat dicapai secara efektip dan efisien. Berdasarkan hasil pengamatan dan studi dokumen bahwa program bimbingan social dan keterampilan yang selama ini dilaksanakan oleh PSKW Ruhui Rahayu di Palangka Raya belum optimal mencapai tujuan yang telah ditetapkan. Program bimbingan social dan keterampilan selama ini dilaksanakan belum memadai untuk meningkatkan kemandirian bagi warga belajar. Berdasarkan fenomena diatas peneliti tertarik untuk mengkaji tentang Strategi Pelayanan Bimbingan Sosial dan Keterampilan pada PSKW Ruhui Rahayu di Palangka Raya.

Penelitian ini bertujuan untuk memperoleh gambaran tentang strategi pelayan bimbingan soaial dan keterampilan pada PSKW Ruhui Rahayu di Palangka Raya, 
secara operasional penelitian ini dimaksudkan untuk memperoleh gambaran nyata tentang strategi : 1) Perencanaan pelayanan bimbingan sosial dan keterampilan pada PSKW Ruhui Rahayu di Palangka Raya, 2). Pengorganisasian, pelayanan bimbingan sosial dan keterampilan pada PSKW Ruhui Rahayu di Palangka Raya. 3) Pelaksanaan pelayanan bimbingan sosial dan keterampilan pada PSKW Ruhui Rahayu di Palangka Raya, 4) dan strategi Evaluasi Pelaksanaan pelayanan bimbingan sosial dan keterampilan pada PSKW Ruhui Rahayu di Palangka Raya.

\section{Metode Penelitian}

Penelitian ini menggunakan metode deskriptif kualitatif dengan rancangan studi kasus (Bogdan \& Biklen, 1082). Subjek dalam penelitian ini ada 2 (dua) orang panitia, 4 (empat) orang pekerja sosial , 17 Orang intsuktur dan 16 orang warga belajar. Lokasi penelitian di wilayah Kota Palangka Raya, tepatnya pada PSKW Ruhui Rahayu Provinsi Kalimantan Tengah. Jl. Rajawali No. 123 Palangka Raya. Instrumen penelitian adalah peneliti sendiri. Peneliti menyadari bahwa dirinya merupakan perencana, pelaksana pengumpul data, Analisis, penafsir data dan pengimplementasi ( Moleong, 1992;168).

Sumber data dalam penelitian ini yaitu data primer dan data skunder. Data primer dalam bentuk verbal kata-kata/ucapan lisan dan perilaku dari subjek berkaitan langsung dengan bimbingan social dan keterampilan, sedangkan data sekunder bersumber dari dokumen sebagai pelengkap data primer karakteristik data sekunder berupa tulisan-tulisan, gambar berhubungan dengan bimbingan social dan keterampilan. tehnik pengumpulan data yaitu dengan tehnik wawancara, observasi dan dokumentasi. Data yang terkumpul diolah dianalisiskan dengan tahap reduksi data, penyajian data, dan penarikan kesimpulan. Untuk menjamin validitas data dilakukan dengan triangulasi yaitu melalui sumber data lain dari sumber data utama.

\section{PEMBAHASAN}

Strategi pelayanan bimbingan sosial dan keterampilan pada PSKW Ruhui Rahayu di Palangka Raya meliputi :

1. Perencanaan 
Dalam kegiatan perencanaan pelayanan yang dilakukan oleh pekerja sosial adalah identifikasi kebutuhan, rekrutmen sumber belajar dan warga belajar, desain kegiatan pelayanan, tujuan program, penyusunan materi, target program pelayanan, sarana dan pendanaan program pelayanan. Saiful Sagala (2009:83) mengatakan perencanaan pada hakekat merupakan kumpulan tindakan secara sistematis disusun dan dilaksanakan berdasarkan data yang dapat dipertanggung jawabkan serta dapat dipergunakan sebagai pedoman kerja. dan Rahman Saleh, (2009: 125) mengatakan perencanaan dapat diartikan sebagai proses pengambilan berbagai keputusan yang dilaksanakan guna mencapai tujuan yang telah ditetapkan. Perencanaan dibagi atas 3 (tiga) kegiatan yaitu : (1) Identifikasi kebutuhan; (2) Rancangan desain kegiatan; (3) Pengadaan dan pemilihan media.

2. Pengorganisasian

Untuk memperlancarkan pelayanan bimbingan sosial dan keterampilan pada PSKW Ruhui Rahayu di Palangka Raya, dibentuk susunan tim yang terdiri dari panitia, pekerja social, fasilitas/Instruktur, pembuatan modul/materi, serta penyelenggaraan test yang masing-masing memiliki tugas pokok dan fungsi yang jelas. Dalam penyelenggaraan kegiatan pelayanan bimbingan sosial dan keterampilan dilakukan pembagian tugas yaitu sebagai penanggung jawab administrasi, penanggung jawab harian dengan rincian tugas masing-masing. Panitia bertugas untuk merencanakan, memonitor, mengorganisir, menilai pelaksanaan dan pelaporan kegiatan pelayanan bimbingan sosial dan keterampilan. Insruktur bertugas dalam merencanakan, melaksanakan dan menilai kegiatan pembelajaran. Panitia pelaksanaan ujian bertugas untuk mempersiapkan,, melaksanakan, mengawasi, memeriksa dan melaporkan hasil ujian praktek. Djudju Sudjana, (2006;22) mengatakan bahwa pekerja sosial, panitia, dan Instruktur bertugas untuk merencanakan, memonitor, mengorganisir, menilai pelaksanaan dan melaporkan hasil kegiatan yang dicapai. Daryanto, (2010:83). Mengatakan Pengorganisasian pelayanan bimbingan social dan keterampilan adalah suatu sistem yang mempunyai struktur dengan bagianbagian pekerjaan yang memiliki tugas dan tanggung jawab, karena pengorganisiaan merupakan suatu wadah yang digunakan sebagai tempat pelayanan bimbingan sosial dan keterampilan bagi warga belajar baik 
melaksanakan teori maupun praktek sehingga memperoleh keterampilan yang diharapkan oleh warga belajar supaya dapat mandiri dan bertanggung jawab sendiri. Pada tahap persiapan pelayanan kegiatan pokok perngorganisasian merupakan upaya untuk menetapkan, menyusun, memadukan dan merumuskan kebutuhan, tenaga, (Panitia, pekerja sosial, Instruktur, Calon Warga Belajar). Sarana dan tugas-tugas pekerjaan yang akan dilaksanakan untuk mencapai tujuan. Pada tahap pelaksanaan kegiatan pelayanan adalah penerapan berbagai pekerjaan dari orang-orang yang terlibat (Panitian, Pekerja social, Instruktur, Calon Warga Belajar, yang memiliki Tugas dan Tanggung Jawab. Adapun kegiatan yang akan dilaksanakan adalah penerapan jadwal pelajaran, penilaian terhadap warga belajar, dan pada akhir pelaksanaan kegiatan yaitu kegiatan penilaian terhadap hasil belajar warga belajar, penilaianan terhadap penyelenggaraan monitoring dan tindak lanjut.

3. Pelaksanaan.

Pelaksanaan kegiatan merupakan kunci yang terpenting dari strategi pelayanan. Pelaksanaan merupakan perwujudan serangkaian tindakan nyata dari rencana yang telah ditetapkan merupakan inti untuk mencapai tujuan yang telah ditentukan secara epektif dn efisien Manulalang, (2006:11) mengatakan Pelaksanaan kegiatan dilakukan dalam 3 (tiga) tahap yaitu (1) tahap persiapan kegiatan meliputi penentuan dan seleksi orang-orang yang terlibat seperti Panitia, Instruktur dan warga belajar, kelengkapan administrasi dan teknis meliputi Panduan daftar registrasi warga belajar,kegitan pelayanan, anggaran, jadwal/waktu, untuk mengalokasi ruang kelas, peralatan belajar, Instruktur, Panitia dan pendaftaran calon warga belajar serta penilaian; (2) Tahap pelaksanaan kegiatan meliputi proses kegiatan pembelajaran dalam upaya meningkatkan kemauan dan kemampuan warga belajar maka perlu adanya kejelasan program untuk menciptakan iklim yang kondusip untuk mencapai tujuan belajar yang efektip tergantung pada pemilihan dan penerapan antara latihan materi kegiatan, metode dan prinsip-prinsip belajar serta penerapannya. (3) Tahap akhir pelaksanaan, merupakan proses kegiatan pembelajaran untuk mencapai tujuan, melalui persiapan laporan akhir, penyajian laporan, pengelolaan kegiatan, monitoring dan evaluasi. 
4. Evaluasi.

Evaluasi pelayanan Bimbingan sosial dan keterampilan dilakukan dengan evaluasi tingkat reaksi, evaluasi tingkat belajar, evaluasi tingkah laku dan evaluasi tingkat dampak. Evaluasi merupakan perwujudan dari bentuk pengawasan. Pengawasan adalah proses penentuan apa yang harus dicapai, mengevaluasi pelaksanaan untuk mengetahui kalau ada yang perlu diperbaiki sehingga pelaksanaan sesuai dengan rencana. Kegiatan pengawasan adalah untuk menentukan standar-standar yang akan digunakan, mengukur dan mengevaluasi pelaksanaan hasil yang dicapai, membandingkan pelaksanaan atau hasil dengan standar untuk mengetahui apakah terjadi penyimpangan kalau ada, melaporkan hasil yang dicapai dan melakukan tindakan perbaikan agar pelaksanaan tujuan sesuai dengan rencana. Dalam kegiatan pelatihan, pengawasan diwujudkan dalam bentuk evaluasi terhadap pelatihan.

5. Evaluasi Tingkat Reaksi (Reaction)

Evaluasi ini dilakukan setiap akhir pelajaran/ setiap pergantian materi pelajaran, kaitannya dalam evaluasi pelayanan bimbingan sosial dan keterampilan, karena evaluasi ini perlu dilakukan untuk melengkapi evaluasi yang dilaksanakan dalam bentuk pengawasan terhadap proses kegiatan pelatihan oleh penanggung jawab program kegiatan itu.

a. Evaluasi Tingkat Belajar (Learning)

Evaluasi tingkat belajar dimakksudkan untuk mengetahui sejauhmana penguasaan pengetahuan dan penguasaan sikap dalam mewujudkan pelayanan bimbingan sosial dan keterampilan setelah mengikuti berbagai macam pelatihan yang mengacu pada indikator pelayanan bimbingan social dan keterampilan.

b. Evaluasi Tingkat Tingkah Laku (Behaviour)

Evaluasi ini dillakukan untuk mengetahui bagaimana tingkat kemampuan kepribadian warga belajar pada saat melaksanakan tugas magang diperusahaan swasta sebagai mitra kerja yang profesional, evaluasi ini baru bisa dilaksanakan pada saat warga belajar sudah melaksanakan tugas dilapangan.

c. Evaluasi Tingkat dampak (Resutl). 
Hamalik, (2006:34) mengatakan Evaluasi ini dilakukan dengan membandingkan prestasi warga belajar sebelumnya dengan prestasi yang baru diperoleh, secara keseluruhan diaplikasikan dalam kegiatan bimbingan sosial dan keterampilan hal ini dilakukan melalui 2 (dua) proses yaitu evaluasi tingkat reaksi dan evaluasi tingkat belajar. Sedanngkan evaluasi hasil (evaluasi tingkat perilaku dan evaluasi tingkat dampak) dilakukan dalam pelaksanaan bimbingan sosial dan keterampilan pada PSKW Ruhui Rahayu di palangka Raya.

Dalam tujuan penelitian ini Perencanaan pelayanan bimbingan social dan keterampilan pada PSKW Ruhui Rahayu di Palangka Raya yang ingin dicapai. Djudju Sudjana (2001) mengemukakan bahwa pada hakekatnya perencanaan merupakan usaha sadar, terorganisir, dan terus menerus dilakukan untuk memilih alternative guna mencapai tujuan”. Selanjutnya Djudju Sudjana (2000) menyatakan bahwa diarahkan pada pencapai tujuan-tujuan melelui penggunaan sarana yang tersedia. Namun keadaan dilapangan ternyata sudah ada persamaan dan tentu tidak seluruhnya selalu bersentuhan, karena faktor kesiapan pihak penyelenggara pelayanan bimbingan sosial. Sehingga apa yang disebut perencanaan merupakan awal untuk melaksanakan strategi manajemen. Perencanaan merupakan faktor yang sangat mendasar untuk menentukan keberhasilan dalam pencapaian tujuan pelayanan bimbingan sosial dan keterampilan. Dari kenyataan tersebut bahwa perencanaan pelayanan bimbingan sosial dan keterampilan merupakan suatu proses yang sistematis dalam pengambilan keputusan tentang tindakan yang akan dilakukan pada waktu yang akan datang untuk mencapai tujuan pelayanan yang telah ditetapkan. Kenyataan dilapangan membuktikan bahwa teori yang ditetapkan diatas tenyata sesuai dengan program pelayanan bimbingan sosial dan keterampilan dengan berpedoman pada penyelenggaraan PSKW Ruhui Rahayu di Palangka Raya.

1. Pengorganisasian.

Pengorganisasian pelayanan bimbingan sosial dan keterampilan pada PSKW Ruhui Rahayu yang ingin dicapai. Sehubungan dengan teori Handoko (1991:168) menyatakan bahwa “Pengorganisasian merupakan suatu proses untuk merancang struktur formal, mengelompok, mengatur serta membagi tugas-tugas pekerjaan diantara para anggota organisasi agar tujuan organisasi dapat tercapai dengan efisien". Hasibuan (1990) mengartikan pengorganisasian 
adalah" suatu proses untuk menentukan, mengelompokan tugas, dan peraturan secara bersama, aktivitas untuk mencapai tujuan, orang-orang yang akan melakukan aktivitas, menentukan wewenang yang $t$ didelegasikan kepada setiap individu yang akan melaksanakan aktivitas tersebut “. Berdasarkan teori di atas ternyata sesuai dengan keadaan dilapangan menunjukan bahwa pengorganisasian pelayanan bimbingan sosial dan keterampilan dilaksanakan secara optimal dengan memperhatikan prinsip-prinsip pengorganisasian hal ini terlihat dengan adanya ; (1) penetapan struktur; (2) penetapan wewenang dan tanggung jawab bagi pimpinan dan seluruh personil yang terlibat dalam organisasi.

2. Pelaksanaan.

Pelaksanaan pelayanan bimbingan sosial dan keterampilan pada PSKW Ruhui Rahayu, jika dihubungkan dengan teori Ishak Abdulhak (2000) mengungkapkan bahwa " untuk mempermudah terjadinya pelaksanaan kegiatan pelayanaan hendaknya penyelenggaraan kegiatan pelatihan mempersiapkan terlebih dahulu kriteria dalam menyeleksi peserta, membuat pedoman penetapan jadwal kegiatan pelayanaan, instruksi belajar dan menyiapkan sarana dan fasilitas”. Pelaksanaan kegiatan bimbingan sosial dan keterampilan dilakukan oleh Tim pekerja social, dan panitia di PSKW Ruhui Rahayu. Berdasarkan data bahwa proses bimbingan sosial dan keterampilan dengan melakukan pelaksanaan pembelajaran, pelaksanaaan pelatihan dan penciptaan suasana yang menyenangkan. Hal ini sejalan dengan pendapat Prawito R.H (1996) mengemukakan bahwa " Proses pelayanan kegiatan pelatihan merupakan suatu kegiatan berlansungnya belajar itu sendiri. Belajar merupakan suatu kegiatan yang bertujuan untuk mengembangkan diri melalui proses penyesuaian tingkah laku dalam upaya untuk meningkatkan kualitas hidupnya". Dari hasil penelitian diketahui bahwa pihak penyelenggara kegiatan bimbingan social dan keterampilan dilaksanakan melalui tahapan-tahapan kegiatan yang didasarkan pada assesmen kebutuhan kegiatan pelayanan. Tahapan penyelenggaan pelaksanaan kegiatan tersebut yaitu : (1) assesmen kebutuhan; (2) penentuan tujuan kegiatan; (3) penentuan materi kegiatan; (4) penetapan panduan pelayanan' (5) penentuan instruktur; (6) penentuan metode dan media; (7) menentukan fasilitas; (8) penentapan anggaran dan (9) penetapan jadwa/waktu pelayanan. 
3. Evaluasi.

Berdasarkan analisis data menunjukan bahwa pengaruh yang diperoleh warga belajar setelah mengikuti kegiatan bimbingan sosial dan keterampilan di PSKW Ruhui Rahayu adalah terbukanya kesempatan yang memberikan pengaruh terhadap pendirian dan peningkatan pendapatan warga belajar. Hal ini sesuai dengan pendapat Sugiyono (2009:112) menjelaskan bahwa evaluasi tingkat reaksi yaitu proses memberikan reaksi dalam bentuk pendapat dan sikap tentang instruktur, cara menyajikan, keguanaan dan perhatian atas materi pelajaran, kesungguhan dan keterlibatan warga belajar dalam mengikuti kegiatan keterampilan. Evaluasi ini dilakukan pada setiap akhir pembelajaran, atau setiap penggantian materi pelajaran. Evaluasi tingkat belajar dimaksudkan untuk mengetahui sejauhmana penguasaan pengetahuan dan perubahan perkembangan sikap. Berdasarakan fakta dilapangan bahwa pelaksanaan evaluasi sesuai dengan teori ysng digunakan yaitu terjadi perubahan hidup yang ditandai dengan perolehan pekerjaan atau mandiri, sehingga terjadi peningkatan pendapatan untuk memenuhi kebutuhan hidup.

\section{KESIMPULAN}

Perencanaan pelayanan bimbingan sosial dan keterampilan pada PSKW Ruhui Rahayu di Palangka Raya telah direncanakan dengan cukup baik oleh pengelola yang berpedoman pada tahapan kegiatan yang berkaitan dengan assesmen kebutuhan pelayanann dan desain kegiatan, penentuan tujuan pelayanan, dan penetapan materi panduan pelayanan.

1. Pengorganisasian pelayanan bimbingan sosial dan keterampilan dilaksanakan dengan baik dimana dalam pengorganisasi bimbingan sosial tersebut dilakukan secara optimal dengan memperhatikan prinsip-prinsip organisasi, hal ini terlihat dengan adanya, penetapan struktur organisasi dan pembagian tugas serta penetapan wewenang dan tanggung jawab bagi pimpinan dari seluruh personil yang terlibat dalam organisasi, untuk mencapai tujuan program yang telah ditetapkan.

2. Pelaksanaan pelayanan bimbingan sosial dan keterampilan telah dilaksanakan dengan baik dan sesuai dengan harapan panitia dan pekerja sosial melalui 
tahapan-tahapan seperti penetapan materi panduan pelayanan, penetapan Instruktur, penetapan metode dan media belajar.

3. Evaluasi (pengawasan) pelayanan sosial dan keterampilan secara prosedural sudah dilaksanakan secara efektip, hal ini terlihat dari evaluasi yang dilaksanakan, yaitu evaluasi tingkat reaksi, evaluasi tingkat belajar, evaluasi tingkat perilaku dan evaluasi tingkat dampak.

\section{DAFTAR PUSTAKA}

Adulhak, Iskhak, (2000) Strategi Pembelajaran PLS. UPI. Bandung.

Burhanuddin, (1994). Analisis Administrasi Manajemen dan Kepemimpinan Pendidikan Jakarta Bumi Aksara.

Dharma A. ( 1998)). Perencanaan Pelatihan. Jakarta, Pusdiklat Pegawai Depdikbud.

Fattah N. (2002). Landasan Manajemen Pendidikan. PT. Remaja Rosdakaya Bandung.

Hasibuan, (1987). Manajemen Dasar, Pengertian dan Masalah, CV.H. Masagung Jakarta.

Prawito, R.H. (1980). Ekonomi Sumber Daya. Bandung Alumni.

Moleong Lexy J. (2003). Metodologi Penelitian Kualitatif. Remaja Rosda Karya Bandung.

Manulang, (2006) Manajemen Sumber Daya Manusia, Jakarta, Rineka Cipta.

Sudjana Djudju, (2001). Metode dan Tehnik Pembelajaran Partisipatif dalam PLS. Falah Production Bandung.

Sugiyono, (2015) Metode Penelitian Kuantatif dan Kualitatif dan $R \& D$. Alfabeta. Bandung.

Saiful Sagalla,(2009:83) Manajemen dalam peningkatan Mutu Pendidikan. Bandung Alfabet.

Anomyn. (2000). Pendidikan Luar Sekolah Wawasan Sejarah Perkembangan Filsafat

Teori Pendudkung Azas. Falah. Production Bandung. 